\title{
BRPKM
}

Buletin Riset Psikologi dan Kesehatan Mental

http://e-journal.unair.ac.id/index.php/BRPKM

e-ISSN: 2776-1851

ARTIKEL PENELITIAN

\section{Studi Fenomenologi: Pengalaman Friends with Benefits pada Pengguna Tinder}

Winda Gladyshavira*

Fakultas Psikologi Universitas Airlangga

\begin{abstract}
ABSTRAK
Penelitian ini bertujuan untuk mengetahui pengalaman hubungan friends with benefits para pengguna Tinder. Metode yang digunakan adalah metode penelitian kualitatif dengan pendekatan fenomenologi. Teknik penggalian data yang digunakan pada penelitian ini adalah wawancara mendalam kepada partisipan yang pernah menjalani hubungan friends with benefits dan pengguna Tinder. Partisipan pada penelitian ini berjumlah dua orang. Teknik analisis yang digunakan adalah Interpretative Phenomenological Analysis (IPA) dengan tahapan penyusunan transkrip wawancara, pencatatan awal, merumuskan tema emergen, merumuskan tema superordinat, membuat pola pengalaman antarpartisipan dan melaporkan hasil. Hasil penelitian ini menemukan bahwa: a) proses pencarian pasangan FWB melalui Tinder melibatkan kesan khas yaitu kesan sensual meskipun diwujudkan dengan pengalaman unik masing-masing partisipan. b) pemaknaan hubungan FWB bermacam-macam, yaitu hubungan untuk having fun, teman tapi mesra, dan pemuas kebutuhan seksual. c) pemaknaan pasangan friends with benefits sebagai teman dan sex partner. Meskipun setiap partisipan memaknai hubungan FWB-nya secara berbeda, satu-satunya poin kesepakatannya adalah aktivitas seksual.
\end{abstract}

Kata kunci: friends with benefits, hyperpersonal, Tinder

\section{ABSTRACT}

This study explores the experience of FWB among Tinder users. Phenomenological approach is used in this qualitative study. Type of data-collection used in this study is in-depth interviews. There are 2 participants in this study. Analysis technique used in this study is Interpretative Phenomenological Analysis with the composition reading and re-reading, initial noting, developing emergent themes, searching for superordinate themes, looking for patterns across cases and reporting result. The result of this study found that: a) the process of finding a FWB partner through Tinder involves a distinctive impression, namely a sensual impression even though it is manifested by the unique experience of each participant. b) There are multiple interpretations of FWB relationship: fun encounter, intimate friendship, and sexual desire fulfillment. c) Presumption of FWB relationship partner as a friend and sex partner. Although each participant interpreted their FWB relationship differently, the only point of agreement was sexual activity.

Keywords: friends with benefits, hyperpersonal, Tinder

Buletin Penelitian Psikologi dan Kesehatan Mental (BRPKM), 2021, Vol. 1(1), 819-828

*Alamat korespondensi: Fakultas Psikologi Universitas Airlangga, Kampus B Universitas Airlangga Jalan

Airlangga 4-6 Surabaya 60286. Surel: winda.gladyshavira-2016@psikologi.unair.ac.id 
Naskah ini merupakan naskah dengan akses terbuka dibawah ketentuan the Creative Common Attribution License (CC-BY-4.0) (http://creativecommons.org/licenses/by/4.0), sehingga penggunaan, distribusi, reproduksi dalam media apapun atas artikel ini tidak dibatasi, selama sumber aslinya disitir dengan baik.

\section{PEN D A H U L U A N}

Fenomena Friends with Benefits atau FWB akhir-akhir ini mulai akrab di telinga. Di Indonesia sendiri pengalaman terhadap fenomena tersebut seringkali dibagikan di sosial media. Dalam pencariannya pada Google dengan kata kunci "Fenomena FWB di Indonesia", muncul beberapa media online yang mencoba membahas mengenai seperti apa fenomena ini, seperti definisi, ciri-ciri, bahkan forum diskusi yang membahas keuntungannya, dan lain-lain. FWB merupakan salah satu bentuk tipe hubungan seksual modern atau dapat dikatakan merupakan salah satu bentuk casual sex (Wentland \& Reissing, 2011). Casual sex adalah bentuk umum dari pertemuan seksual yang terjadi di antara para dewasa muda dan mewakili jenis hubungan seksual modern. FWB merupakan hubungan yang cukup kompleks (Wentland \& Reissing, 2014). Hubungan FWB adalah hubungan pertemanan yang terlibat secara seksual, tetapi tidak secara romantis (Lehmiller dkk., 2011). Jika dilihat hubungan tersebut menggambarkan definisi hubungan romantis yang sesungguhnya, seperti terdapat keintiman dan gairah seksual, akan tetapi hal penting yang perlu disadari bahwa pasangan FWB tidak menganggap keterlibatan mereka sebagai sebuah hubungan romantis.

Motif seseorang menggunakan aplikasi kencan daring bermacam-macam. Fungsi sebuah aplikasi kencan daring ditentukan oleh orang-orang yang menggunakannya. Sebuah penelitian menyatakan bahwa internet telah menjadi alat umum yang digunakan untuk mencari teman, pasangan romantis, dan pasangan seksual (Couch \& Liamputtong, 2008). Selain itu, sebuah penelitian di Amerika Serikat menemukan 9,8\% dari orang yang menggunakan internet untuk aktivitas seksual daring menggunakannya untuk memfasilitasi aktivitas seksual secara langsung (Cooper dkk., 2002). Penelitian lain dilakukan di Swedia pada tahun 2002 disebarkan kuisioner online dan hasilnya 1.458 orang menggunakan internet untuk tujuan seksual dari total populasi 1.836 responden, diantaranya 35\% pria dan 40\% wanita dilaporkan telah bertemu pasangan seks secara langsung (Daneback dkk., 2007).

Menurut pernyataan seorang peneliti dari University of Sydney, Dr Mitchell Hobbs, kepada Bustle, beberapa aplikasi dipandang sebagai sarana untuk mencari casual sex, contohnya Tinder (Emery, 2016). Pada tahun 2019, Tinder juga dianggap aplikasi kencan daring yang paling populer di Amerika Serikat karena jumlah penggunanya yang paling banyak dibandingkan dengan aplikasi kencan daring lainnya (Tankovska, 2021). Di Indonesia, beberapa aplikasi kencan daring yang cukup populer yaitu Tinder, Setipe, OKCupid, Badoo, dan Tantan (Ardaningtyas, 2020).

Sebanyak 163 orang emerging adult di Belanda pengguna Tinder yang berusia 18 hingga 30 tahun diminta untuk mengisi survei daring mengenai motivasi menggunakan aplikasi Tinder (Sumter dkk., 2017). Hasil dari survei daring tersebut mengatakan bahwa terdapat enam motivasi seseorang menggunakan Tinder, yaitu cinta, casual sex, kemudahan berkomunikasi, validasi harga diri, sensasi kegembiraan, dan mengikuti trend. Menurut survei yang dilakukan di Indonesia pada 512 pengguna Tinder, hasilnya mengaku menggunakan aplikasi tersebut hanya untuk mengisi waktu luang, berjejaring, mencari hiburan, mencari pasangan potensial, mencari rekan bisnis, dan mengamati pengguna lain (Kresna, 2017). Dari fakta-fakta penelitian tersebut, dapat dilihat bahwa terdapat perbedaan hasil survei di Indonesia dengan penelitian yang sudah dilakukan di luar negeri. Survei di Indonesia tidak ditemukan bahwa pengguna Tinder menggunakan aplikasi tersebut untuk mencari 
pasangan seks. Kontras dengan hasil survei tersebut, penulis menemukan salah satu pengguna menunjukkan biodata pada profil pengguna Tinder yang dengan jelas menyebutkan mengenai pencarian pasangan FWB.

Melihat hasil salah satu penelitian bahwa FWB salah satu jenis casual sex, maka penulis beranggapan bahwa sangat mungkin pencarian Friends with Benefits dilakukan melalui aplikasi kencan daring ini (Wentland \& Reissing, 2011). Oleh karena itu, penulis tertarik untuk menggambarkan fenomena pasangan seksual (casual sex partner) khususnya Friends with Benefits para pengguna Tinder.

\section{Desain Penelitian}

\section{E T O D E}

Penelitian ini menggunakan metode penelitian kualitatif yang merupakan metode penelitian bersifat deskriptif alamiah dengan menginterpretasi suatu keadaan dalam konteks pemahaman partisipan terhadap pengalaman yang mereka alami (Raco \& Tanod, 2012). Pendekatan yang dilakukan pada penelitian kualitatif ini adalah pendekatan fenomenologi. Pendekatan ini menekankan cara transendensi diri yang menghubungkan kesadaran dengan objek lain, untuk mengungkapkan aspek tersembunyi dari pengalaman individu (Matua \& Van Der Wal, 2015). Dengan pendekatan ini, peneliti mencoba memahami gambaran fenomena partisipan yang diteliti dengan menggunakan logika serta teori-teori yang sesuai untuk melihat bagaimana pengalaman para pengguna Tinder dalam menjalani hubungan Friends with Benefits serta bagaimana mereka memaknainya.

\section{Partisipan}

Kriteria partisipan yang terlibat pada penelitian ini yaitu: (1) seseorang yang pernah atau sedang menggunakan Tinder; (2) pernah memiliki pasangan FWB yang dikenal melalui Tinder; (3) bersedia menjadi partisipan penelitian selama penelitian ini dilakukan. Partisipan dalam penelitian ini berjumlah dua orang, satu partisipan berjenis kelamin laki-laki dan partisipan lain berjenis kelamin perempuan. Partisipan laki-laki berusia 26 tahun, sedangkan partisipan perempuan berusia 25 tahun. Status hubungan tiap partisipan dalam penelitian ini berbeda, partisipan perempuan saat ini sedang menjalani hubungan ekslusif dan partisipan laki-laki tidak sedang berada dalam hubungan eksklusif. Penggalian data dilakukan dengan wawancara mendalam kepada setiap partisipan. Wawancara mendalam merupakan wawancara yang bersifat lebih fleksibel, terbuka, tidak berstruktur ketat, dan tidak dalam suasana formal (Nugrahani, 2014). Meskipun melakukan wawancara mendalam, pedoman wawancara tetap digunakan pada penelitian ini. Sebelum memulai wawancara, kedua partisipan diberikan informed consent yang berisi tentang kesediaan untuk berpartisipasi dalam penelitian ini.

\section{Analisis Data}

Analisis yang digunakan pada penelitian ini adalah Interpretative Phenomenological Analysis (IPA) yang memiliki empat langkah yaitu penyusunan transkrip wawancara, pencatatan awal, merumuskan tema emergen, merumuskan tema superordinat, membuat pola pengalaman antarpartisipan dan melaporkan hasil.

\section{HAS IL P ENELIT IAN}

Hasil penelitian dianalisis menggunakan metode Interpretative Phenomenological Analysis (IPA). Setiap partisipan memiliki pola unik mengenai pengalaman FWB dalam menggunakan aplikasi Tinder. Bermula dari pengunduhan aplikasi Tinder pada smartphone yang dimiliki. Kedua partisipan menarik pasangannya melalui Tinder dengan mengoptimalkan fitur-fitur yang ada pada profil masing-masing. Setelah itu, para partisipan akan memilih pasangan-pasangan potensial yang sesuai dengan preferensi 
pasangan yang menurut keduanya menarik. Jika beruntung, akan berlanjut pada tahap match. Setelah match dengan beberapa pasangan potensial, kedua partisipan akan memilih pasangan FWB potensial setelah melakukan seleksi melalui obrolan yang menarik dan jika pasangan FWB potensial memiliki boyfriend atau girlfriend material. Boyfriend atau girlfriend material adalah hal-hal yang dimiliki pasangan ideal menurut masing-masing partisipan. Percakapan terjadi pada ruang obrolan Tinder. Percakapan yang terjadi melibatkan percakapan-percakapan sensual di dalamnya supaya dapat terjadi pertemuan yang melibatkan aktivitas seksual.

Hubungan FWB bagi masing-masing partisipan ditemukan memiliki makna masing-masing bagi tiap partisipan. Pada partisipan perempuan memaknai hubungan FWB adalah hubungan untuk having fun, sedangkan pada partisipan laki-laki hubungan FWB merupakan hubungan teman tapi mesra. Hanya saja, keduanya memiliki pemaknaan yang sepaham bahwa hubungan FWB sebagai pemenuhan kebutuhan seksual. Kedua partisipan juga memaknai pasangan FWB-nya hanya sebagai teman, meskipun berbagai perasaan timbul selama menjalani hubungan FWB ini. Perasaan-perasaan yang timbul selama menjalani hubungan FWB ini adalah penasaran, gugup, excited, unexplained, bosan, kapok, ketagihan, dan nyaman. Penasaran, gugup, dan excited timbul pada awal sebelum terjadi pertemuan, perasaan-perasaan tersebut yang mendorong supaya terjadinya pertemuan. Perasaanperasaan lainnya seperti unexplained, bosan, kapok, ketagihan, dan nyaman mengarahkan akhir dari hubungan FWB yang dijalani para partisipan. Perasaan unexplained, bosan, kapok, dan ketagihan mendorong partisipan untuk mengakhiri hubungan FWB-nya, sedangkan perasaan nyaman membuat partisipan mengembangkan hubungannya menjadi hubungan eksklusif yaitu pacaran.

\section{I S K U S I}

Seseorang pasti memiliki alasan tertentu dalam memulai hubungan FWB. Berakhirnya hubungan romantis sebelumnya membuat kedua partisipan memutuskan untuk menghindari hubungan dengan komitmen. Sejalan dengan hal tersebut, sebuah penelitian menunjukkan bahwa hubungan FWB diinginkan karena dalam hubungan ini melibatkan kepercayaan dan kenyamanan, sementara menghindari komitmen dari hubungan romantis (Bisson \& Levine, 2009). Kedua partisipan penelitian ini menunjukkan alasan yang sama ketika memutuskan untuk memulai hubungan FWB, yaitu menghindari komitmen. Komitmen adalah niat untuk bertahan dalam suatu hubungan, termasuk orientasi jangka panjang terhadap keterlibatan serta perasaan keterikatan psikologis (Rusbult dkk., 1998). Menurut partisipan perempuan, pada dasarnya dirinya tidak menyukai komitmen hubungan romantis. Pada partisipan laki-laki, komitmen hubungan romantis yang dihindari merupakan akibat dari tidak berhasilnya hubungan sebelumnya. Ketika seseorang menyadari dirinya secara sadar takut tidak dicintai, ketakutan yang sebenarnya, meskipun biasanya tidak disadari adalah cinta (Fromm, 1956). Fromm mengatakan bahwa mencintai berarti berkomitmen pada diri sendiri tanpa jaminan, memberikan diri sepenuhnya dengan harapan cinta tersebut akan menghasilkan cinta pada orang yang dicintai. Cinta adalah tindakan dari sebuah keyakinan, dan siapa pun yang memiliki sedikit keyakinan juga memiliki sedikit cinta. Ketika seseorang kehilangan keyakinan dalam sebuah hubungan, seseorang akan melakukan rasionalisasi atas hilangnya keyakinan tersebut. Menghindari komitmen untuk berada pada hubungan romantis dapat menjadi bentuk rasionalisasi yang dilakukan akibat hilangnya keyakinan dalam hubungan romantis yang dijalani partisipan laki-laki sebelumnya.

Bermula dari kedua partisipan mengunduh aplikasi Tinder. Hal pertama yang dilakukan pengguna kencan daring adalah mengoptimalkan kesan, yaitu dengan mengunggah foto terbaik yang dianggap menarik pada foto profil akun Tinder masing-masing. Namun, selain mengunggah foto profil pada akun Tinder, salah satu partisipan mencantumkan isyarat khas berupa kalimat sensual pada biodata. Sebagai 
sender, seseorang dapat mencantumkan isyarat-isyarat tertentu yang lebih disukai untuk menampilkan kesan (Walther, 1996). Hal ini menunjukkan bahwa para partisipan mengatur kesan yang ditampilkan pada profil Tinder masing-masing untuk menarik pasangan potensial.

Tidak adanya isyarat tatap muka dan pengetahuan personal terlebih dahulu satu sama lain, isyarat sosial atau isyarat personal yang muncul dalam computer mediated communication akan menjadi nilai yang sangat besar (Walther, 1996). Hal ini juga terjadi pada kedua partisipan. Kedua partisipan mengalami over-atribusi saat melihat isyarat-isyarat yang muncul pada profil pasangan potensial. Isyarat-isyarat yang muncul pada profil pasangan potensial yang dilihat oleh kedua partisipan adalah foto profil pasangan potensial yang menampilkan kriteria fisik sesuai dengan preferensi masing-masing partisipan. Ketika melihat foto profil pasangan potensial yang menampilkan kriteria fisik sesuai dengan preferensi masing-masing partisipan tersebut, kedua partisipan segera melakukan swipe right. Selain profil yang menampilkan foto sesuai dengan preferensi fisik, terdapat isyarat-isyarat lain pada profil pasangan potensial yang menjadi pertimbangan partisipan dalam melakukan swipe right, yaitu jarak, usia, dan biodata yang menggunakan Bahasa inggris. Padahal sebanyak $80 \%$ orang yang menggunakan kencan daring memanipulasi tinggi, berat, dan usianya meskipun hanya kecil, sehingga terkadang tidak terlihat pada saat pertemuan secara langsung (Toma dkk., 2008). Penelitian yang dilakukan sebelumnya juga menunjukkan bahwa pengguna kencan daring secara langsung atau tidak langsung merujuk pada fakta bahwa mereka dengan hati-hati memperhatikan isyarat-isyarat kecil yang terdapat pada profil pasangan lain, dan seringkali tampak mengambil tingkat perhatian yang sama saat menyusun kesan mereka sendiri (Ellison dkk., 2006). Sesuai dengan penelitian ini, kedua partisipan mempercayai isyarat-isyarat yang ditampilkan pada profil pasangan potensial sehingga memutuskan untuk segera swipe right. Ketika setelah partisipan sudah melakukan swipe right dan pasangan potensial lain juga melakukan swipe right pada profil partisipan, maka akan terjadi match.

Pengiriman pesan yang dilakukan melalui computer mediated communication terjadi ketika aktivitas lain individu telah berhenti (Walther, 1996). Setelah terjadi match, pengguna Tinder dapat saling bertukar pesan pada ruang obrolan yang disediakan aplikasi Tinder (Tinder, n.d.). Kegiatan saling bertukar pesan pada aplikasi Tinder oleh kedua partisipan bersifat asynchronous, pesan saling dikirim memiliki jarak waktu. Kedua partisipan membalas pesan sesuai dengan waktu luang yang dimiliki. Jarak waktu pengiriman pesan yang bersifat asynchronous ini membuat pengguna dapat mencari tahu terlebih dahulu hal yang tidak diketahui untuk mengontrol supaya interaksi dengan pasangan potensial yang berhasil match dapat lebih jauh (Walther, 1996). Hal tersebut dilakukan salah satu partisipan, dimana dirinya mencari tahu hal yang disukai pasangan potensial yang berhasil match terlebih dahulu. Setelah itu, partisipan akan mempelajarinya dengan seksama supaya saat membicarakan hal yang disukai pasangan potensial yang telah match tersebut seolah-olah ia memahaminya juga. Partisipan melakukannya dengan sengaja, sehingga nantinya pasangan potensial yang berhasil match merasa nyaman dan tanpa batasan untuk membicarakan mengenai hal apapun.

Kesan yang berusaha dibentuk oleh kedua partisipan mendapatkan respon dari pasangan potensial yang berhasil match. Pada partisipan perempuan, isyarat biodata sensual yang diberikan membuat pasangan potensial yang berhasil match mempertanyakan mengenai hal tersebut. Tidak jarang partisipan perempuan langsung mendapatkan ajakan untuk terjadi aktivitas seksual oleh pasangan potensial yang berhasil match. Partisipan perempuan menerima ajakan tersebut dengan tidak memberi penolakan terhadap topik sensual yang diberikan. Namun, respon lain yang diterima partisipan perempuan juga berupa tidak adanya komunikasi setelah terjadi match. Pada partisipan laki-laki, pasangan potensial yang berhasil match tersebut memberikan respon pada topik pembicaraan sensual yang dilontarkan oleh partisipan. Pengguna perempuan cenderung menunggu, sedangkan pengguna laki-laki cenderung mengajak, atas terjadinya aktivitas seksual. Milhausen dan Herold menyatakan

Buletin Riset Psikologi dan Kesehatan Mental (BRPKM)

2021, Vol. 1(1), 819-828 
bahwa terdapat standar ganda jika berbicara mengenai casual sex (Lehmiller dkk., 2011). Perempuan cenderung dihakimi lebih kasar oleh masyarakat daripada laki-laki untuk keterlibatnannya dalam aktivitas seksual permisif, seperti sering terlibat dalam hubungan casual sex, sehingga partisipan perempuan cenderung hanya menunggu ajakan untuk terjadi aktivitas seksual. Selain itu, respon lain yang diberikan adalah mengijinkan untuk adanya pertemuan aktivitas seksual. Hal ini sejalan dengan elemen feedback pada komunikasi hyperpersonal yang dikemukakan oleh Walther (1996) yang menyatakan bahwa feedback terjadi dimana individu pada dasarnya terlibat dalam bentuk self-fulfilling prophecy dengan membalas dan mewujudkan kesan yang sering diidealkan yang diberikan satu sama lain. Kesan yang dibentuk pada hubungan ini oleh kedua partisipan bersifat sensual, sehingga feedback yang diterima berupa ajakan untuk melakukan aktivitas seksual. Proses yang terjadi pada para partisipan dalam mencari pasangan FWB di aplikasi Tinder menunjukkan terjadinya interaksi hyperpersonal.

Pengalaman partisipan menjelaskan bagaimana respon tertentu akan membawa pada sebuah pertemuan. Pada partisipan perempuan, aktivitas seksual terjadi saat petemuan pertama. Namun, pada beberapa kasus hanya terjadi pertemuan saja di kedai kopi dan terjadi obrolan-obrolan sensual tanpa aktivitas seksual. Berbeda dengan partisipan perempuan, pada partisipan laki-laki, aktivitas seksual terjadi pada pertemuan ke tiga. Selama menggunakan Tinder, partisipan perempuan pernah menjalani hubungan FWB dengan sekitar lima belas orang, sedangkan partisipan laki-laki hanya pernah menjalin hubungan FWB sebanyak dua kali. Hal ini sesuai dengan sebuah penelitian di Swedia kepada 1836 orang, hasilnya 1458 orang menggunakan internet untuk tujuan seksual, dari total populasi 1.836 responden, diantaranya $35 \%$ pria dan $40 \%$ wanita dilaporkan telah bertemu pasangan seksnya secara tatap muka, dimana presentase wanita yang bertemu pasangan seksnya melalui internet lebih banyak dibandingkan dengan laki-laki (Daneback dkk., 2007). Aktivitas seksual yang terjadi pada kedua partisipan yaitu hingga tahap sexual intercourse. Sejalan dengan penelitian lain yang menunjukkan bahwa presentase terbesar dari partisipannya yang menjalani hubungan FWB, yaitu sebanyak $22 \%$, tipe aktivitas seksual yang paling banyak dilakukan adalah sexual intercourse (Bisson \& Levine, 2009)

Partisipan menunjukkan frekuensi aktivitas seksual yang beragam. Pada partisipan perempuan, berbeda pasangan FWB akan membedakan dalam hal frekuensi terjadinya aktivitas seksual tersebut. Mulai dari aktivitas seksual yang hanya terjadi sekali, hingga yang telah putus kontak kemudian saatsaat tertentu menghubungi kembali untuk melakukan aktivitas seksual. Sedangkan pada partisipan lakilaki, aktivitas seksual yang terjadi pada setiap hubungan FWB-nya adalah aktivitas seksual berulang. Kontras dengan hasil penelitian yang dilakukan sebelumnya yang menunjukkan bahwa sebuah hubungan dapat dikatakan FWB apabila aktivitas seksual yang terjadi berulang. Frekuensi aktivitas seksual yang dialami partisipan beragam, yaitu hanya terjadi sekali, saat-saat tertentu, meskipun juga terdapat partisipan yang melakukannya berulang (Levine \& Mongeau, 2010).

Tanpa adanya pembicaraan lebih lanjut mengenai hubungan FWB dengan pasangan FWB-nya, parameter hubungan tersebut disebut hubungan FWB oleh partisipan perempuan adalah ketika sudah terjadi aktivitas seksual. Berbeda pada partisipan laki-laki, hubungan dapat disebut FWB setelah terjadi kesepakatan bersama mengenai sebenarnya apa jenis hubungan yang sedang mereka jalani tersebut. Pembicaraan yang terjadi dengan pasangan FWB pun terjadi setelah pertemuan aktivitas seksual kesekian kalinya. Sebuah penelitian menunjukkan bahwa tidak ada perbedaan gender yang signifikan pada pola komunikasi yang terjadi terkait dengan pembicaraan hubungan saat itu dan masa depan, hal tersebut dianggap mungkin terjadi karena frekuensi komunikasi yang rendah (Bisson \& Levine, 2009). Pada penelitian ini justru terdapat perbedaan signifikan pada komunikasi mengenai hubungan jika dikaitkan dengan gender. Hal tersebut mungkin berkaitan dengan ekspetasi hubungan di masa depan dimana harapan laki-laki dan perempuan atas hubungan FWB berkembang secara berbeda. Para laki- 
laki akan cenderung mengharapkan hubungan yang tetap sama di masa depan. Berbeda dengan lakilaki, perempuan justru menginginkan perubahan menjadi sebuah hubungan romantis yang sesungguhnya atau justru menjadi sekedar murni pertemanan biasa (Lehmiller dkk., 2011). Karena lakilaki ingin hubungan tetap sama di masa depan, mungkin saja partisipan laki-laki justru membicarakan dengan jelas mengenai hubungannya kepada pasangan FWB-nya. Hal ini juga terlihat pada perkembangan hubungan pada kedua partisipan. Partisipan laki-laki berkembang dengan putus kontak, sedangkan partisipan perempuan meskipun juga sebagian besar berakhir dengan putus kontak, terdapat satu pasangan FWB partisipan perempuan yang berkembang menjadi pacar.

Kedua partisipan memiliki satu kesamaan pemaknaan hubungan FWB, yaitu sebagai pemenuhan kebutuhan seksual. Selain itu, keduanya memiliki pemaknaan terhadap hubungan FWB yang berbedabeda. Partisipan perempuan memaknai hubungan FWB-nya sebagai hubungan untuk having fun. Having fun yang dimaksud oleh partisipan perempuan adalah hubungan pertemanan untuk bersenang-senang tanpa terikat status dan komitmen. Sedangkan pada partisipan laki-laki memaknai hubungan FWB-nya sebagai teman tapi mesra, dimana hal-hal yang biasa dilakukan bersama pasangan FWB sama seperti hal-hal yang biasa dilakukan dengan pasangan romantis, namun tanpa ikatan dan perasaan yang terlibat. FWB kurang memiliki ekslusivitas, komitmen, serta keinginan untuk hubungan romantis serta kelekatan emosional (Hughes dkk., 2005).

Dalam pemaknaan pasangan FWB, kedua partisipan juga memiliki pemaknaan pasangan FWB sebagai teman dan sex partner, meskipun dari masing-masing partisipan memiliki maksud yang berbeda. Teman yang dimaksud partisipan perempuan adalah teman tanpa baper. Seperti yang telah dijelaskan, baper adalah akronim dari bawa perasaan atau dapat diartikan melibatkan perasaan. Bagi partisipan laki-laki, makna pasangan FWB adalah teman yang ketika butuh bantuan partisipan laki-laki akan membantu. Partisipan laki-laki merasa sayang dan peduli kepada pasangan FWB-nya, hanya saja perasaan tersebut sebatas perasaan sayang kepada teman. Selain itu, kedua partisipan juga menyepakati bahwa makna pasangan FWB bagi mereka selain sebagai teman adalah sebagai sex partner. Jika dilihat dari pemaknaan pasangan FWB oleh kedua partisipan, maka hal tersebut sesuai dengan pernyataan sebuah penelitian bahwa hubungan FWB menggabungkan manfaat dari pertemanan dengan manfaat dari hubungan seksual, namun menghindari kewajiban dan komitmen yang biasanya terdapat pada hubungan romantis (Hughes dkk., 2005).

Hasil sebuah menunjukkan bahwa setiap partisipan mendeskripsikan hubungan FWB-nya dengan berbagai cara (Mongeau dkk., 2013). Meskipun hubungan FWB setiap partisipan berbeda-beda, satusatunya poin kesepakatannya adalah aktivitas seksual. Setiap partisipan memiliki pemaknaan masingmasing dalam hal hubungan FWB maupun pasangan FWB, namun kesamaan yang dimiliki adalah adanya aktivitas seksual yang terjadi dalam hubungan FWB tersebut.

\section{S I M P U L A N}

Hasil penelitian ini menghasilkan penjelasan tentang pengalaman hubungan FWB para pelaku pengguna Tinder. Pengalaman hubungan FWB dapat diketahui melalui bagaimana proses komunikasi hyperpersonal pencarian pasangan melalui aplikasi Tinder. Sebagai sender, para partisipan mengoptimalkan kesan dengan mencantumkan isyarat-isyarat yang diinginkan pada profil pribadi untuk menarik pasangan potensial, seperti foto profil atau biodata sensual. Kemudian sebagai receiver, para partisipan melakukan atribusi secara berlebihan terhadap isyarat yang dicantumkan pasangan potensial, seperti biodata yang menggunakan Bahasa Inggris dianggap smart ataupun foto profil yang menampilkan preferensi fisik masing-masing partisipan, membuat para partisipan melakukan swipe 
right. Ketika telah terjadi match, terjadinya asynchronous channel membuat pengiriman pesan dilakukan para partisipan sesuai dengan waktu luang yang dimiliki. Waktu yang dimiliki partisipan dapat digunakan untuk mempelajari hal-hal yang disukai pasangan potensial yang berhasil match supaya dapat mengontrol interaksi yang terjadi. Feedback yang diterima para partisipan berupa ajakan pertemuan untuk melakukan aktivitas seksual atau respon berupa match namun tidak ada komunikasi yang terjadi.

Dalam menjalani hubungan FWB, pemaknaan hubungan FWB para partisipan menampilkan pemaknaan yang berbeda pada tiap partisipan. Bagi partisipan hubungan FWB merupakan hubungan untuk having fun, hubungan teman tapi mesra, dan hubungan sebagai pemuas kebutuhan seksual. Sedangkan dalam memaknai pasangan FWB, para partisipan memaknainya sebagai teman dan sex partner.

\section{U C A P A N T ER I MAKASIH}

Terima kasih banyak kepada Bapak Dr. Rahkman Ardi, M.Psych. selaku dosen pembimbing penelitian ini sehingga penelitian ini dapat terlaksana dengan baik. Penulis juga mengucapkan terimakasih banyak kepada pihak yang membantu penulis untuk bertemu dengan partisipan yang sesuai dengan kriteria, serta pihak-pihak lain yang terlibat dalam pelaksanaan penelitian ini yang tidak dapat penulis sebutkan satu persatu.

\section{DEKLARASI POTENSI TERJADINYAKONFLIK KEPENTINGAN}

Winda Gladyshavira tidak bekerja, menjadi konsultan, memiliki saham, atau menerima dana dari perusahaan atau organisasi manapun yang mungkin akan mengambil untung dari diterbitkannya naskah ini.

\section{PUSTAKA ACUAN}

Ardaningtyas, N. (2020). Lima Aplikasi Kencan Online Pilihan. Antara News. https://www.antaranews.com/berita/1735661/lima-aplikasi-kencan-online-pilihan

Bisson, M. A., \& Levine, T. R. (2009). Negotiating a friends with benefits relationship. Archives of Sexual Behavior, 38(1), 66-73. https://doi.org/10.1007/s10508-007-9211-2

Cooper, A., Morahan-Martin, J., Mathy, R. M., \& Maheu, M. (2002). Toward an increased understanding of user demographics in online sexual activities. Journal of Sex and Marital Therapy, 28(2), 105129. https://doi.org/10.1080/00926230252851861

Couch, D., \& Liamputtong, P. (2008). Online dating and mating: The use of the internet to meet sexual partners. Qualitative Health Research, 18(2), 268-279. https://doi.org/10.1177/1049732307312832

Daneback, K., Månsson, S. A., \& Ross, M. W. (2007). Using the Internet to find offline sex partners. Cyberpsychology and Behavior, 10(1), 100-107. https://doi.org/10.1089/cpb.2006.9986

Ellison, N., Heino, R., \& Gibbs, J. (2006). Managing impressions online: Self-presentation processes in the

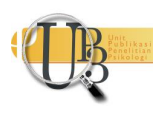


online dating environment. Journal of Computer-Mediated Communication, 11(2), 415-441. https://doi.org/10.1111/j.1083-6101.2006.00020.x

Emery, L. R. (2016). Is Tinder Actually Good For Modern Relationships? Bustle. https://www.bustle.com/articles/186819-tinder-isnt-bad-for-modern-relationships-study-saysso-lets-all-calm-down

Fromm, E. (1956). The Art of Loving.

Hughes, M., Morrison, K., \& Asada, K. J. K. (2005). What's love got to do with it? Exploring the impact of maintenance rules, love attitudes, and network support on friends with benefits relationships. Western Journal of Communication, 69(1), 49-66. https://doi.org/10.1080/10570310500034154

Kresna, M. (2017). Aplikasi Kencan: Cari Jodoh atau Teman Bobo? https://tirto.id/aplikasi-kencan-carijodoh-atau-teman-bobo-ctrR

Lehmiller, J. J., Vanderdrift, L. E., \& Kelly, J. R. (2011). Sex differences in approaching friends with benefits relationships. Journal of Sex Research, 48(2-3), 275-284. https://doi.org/10.1080/00224491003721694

Levine, T. R., \& Mongeau, P. A. (2010). Friends with benefits. In Print and Promo (Vol. 58, Issue 5, pp. 3840).

Matua, G. A., \& Van Der Wal, D. M. (2015). Differentiating between descriptive and interpretive phenomenological research approaches. Nurse Researcher, 22(6), 22-27. https://doi.org/10.7748/nr.22.6.22.e1344

Mongeau, P. A., Knight, K., Williams, J., Eden, J., \& Shaw, C. (2013). Identifying and explicating variation among friends with benefits relationships. Journal of Sex Research, 50(1), 37-47. https://doi.org/10.1080/00224499.2011.623797

Nugrahani, F. (2014). dalam Penelitian Pendidikan Bahasa. 信阳师范学院, 1(1), 305. http://ejournal.usd.ac.id/index.php/LLT\%0Ahttp://jurnal.untan.ac.id/index.php/jpdpb/article/viewFile /11345/10753\%0Ahttp://dx.doi.org/10.1016/j.sbspro.2015.04.758\%0Awww.iosrjournals.org

Raco, J. R., \& Tanod, R. R. H. M. (2012). Metode Fenomenologi Entrepreneurship Aplikasi pada EnterPreneureship. 210.

Rusbult, C. E., Martz, J. M., \& Agnew, C. R. (1998). The Investment Model Scale: Measuring commitment level, satisfaction level, quality of alternatives, and investment size. Personal Relationships, 5, 357391. https://doi.org/10.3115/1667583.1667616

Sumter, S. R., Vandenbosch, L., \& Ligtenberg, L. (2017). Love me Tinder: Untangling emerging adults' motivations for using the dating application Tinder. Telematics and Informatics, 34(1), 67-78. https://doi.org/10.1016/j.tele.2016.04.009

Tankovska, H. (2021). Most Popular Online Dating Apps in the United States as of September 2019, by

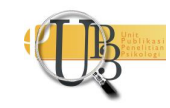


Audience Size. Statista. https://www.statista.com/statistics/826778/most-popular-dating-appsby-audience-size-usa/

Tinder. (n.d.). A Guide to Tinder. https://www.help.tinder.com/hc/en-us/categories/115000755686-AGuide-To-Tinder-

Toma, C. L., Hancock, J. T., \& Ellison, N. B. (2008). Separating fact from fiction: An examination of deceptive self-presentation in online dating profiles. Personality and Social Psychology Bulletin, 34(8), 1023-1036. https://doi.org/10.1177/0146167208318067

Walther, J. B. (1996). Computer Mediated Communication: Impersonal, Interpersonal, and Hyperpersonal Interaction.

Wentland, J. J., \& Reissing, E. (2014). Casual sexual relationships: Identifying definitions for one night stands, booty calls, fuck buddies, and friends with benefits. Canadian Journal of Human Sexuality, 23(3), 167-177. https://doi.org/10.3138/cjhs.2744

Wentland, J. J., \& Reissing, E. D. (2011). Taking casual sex not too casually: Exploring definitions of casual sexual relationships. Canadian Journal of Human Sexuality, 20(3), 75-91. 